\title{
The Relationship Between Tooth Brushing Behavior and Dental Caries in Children in Bandung
}

\author{
Lelly Andayasari $^{1 *}$, Iin Nurlinawati ${ }^{2}$, Soraya Maulia ${ }^{3}$
}

\author{
${ }^{1,2}$ Center for Research and Development of Health Resources and Services, Jl. Percetakan Negara No 29, \\ 10560, Jakarta, Indonesia \\ ${ }^{3}$ Faculty of Dentistry-University of Yarsi, Jl. Letjen Suprapto No. 1, 10510, Jakarta, Indonesia \\ *Corresponding author. Email: andayasari@gmail.com
}

\begin{abstract}
Background: Children with the correct habit of brushing have a smaller incidence of dental caries compared to children who rarely brush their teeth. The survey of Indonesia suggested that the prevalence of behavior tooth brushing increase from 2,3 in 2013 to 2,8 in 2018. Objective: To identify relationship between tooth brushing and caries happening with children at Bandung city. Method: The study was conducted on children aged 4-7 years in the city of Bandung. The research design was cross sectional. The dental health status is examined by a dentist using a sterile standard diagnostic tool. Data on the characteristics and habits brushing teeth are obtained through interviews with their parent using a questionnaire. Data were analyzed by univariate and bivariate using SPSS software. Result: The Correct tooth brushing behavior has a correlation to the occurrence of dental caries $(r=0,521 ; p=0,000)$. Conclusion: Dental caries is more common in children who have incorrect tooth brushing behavior. In this study proper tooth brushing behavior was significantly associated with dental caries. Recommendation: Parents pay attention to children when brushing their teeth. This is to prevent dental caries and other oral diseases.
\end{abstract}

Keywords: tooth brushing behavior, caries, children

\section{INTRODUCTION}

Dental caries is still a problem in development and developing countries. The prevalence of dental caries in Indonesia according to Basic Health Research 2018 is 45.3\%.1 Children must be given knowledge of oral health to prevent dental and oral diseases. Someone must brush their teeth properly and correctly to prevent dental caries and good oral hygiene is maintained. The proportion of daily toothbrushing behavior in the population above 3 years is $94.7 \% .1$ However, the proportion of correct toothbrushing is very low at $2.8 \%$ [1].

The right habit of brushing refers to the Federation Dentaire Internationale (FDI), which is the habit of brushing your teeth every day, at least twice a day, after breakfast and before going to bed at night. The results of research on kindergarten children in Bekasi City in 2016 obtained still very low correct tooth brushing behavior that is $5.8 \%$ [2]. Similarly with the results of Sintawati research in Banten and Yogyakarta [3]. The purpose of brushing teeth after breakfast and before going to bed at night so that there is no food stuck to the surface of the teeth. Food that sticks to the tooth surface can cause dental caries. Dental caries is caused by many factors. These factors are substrate attached to the surface of the teeth, Streptococcus mutans, saliva and time.
Based on the results of Riskesdas 2018, the prevalence of dental caries in the 5-9 years age group was $54.0 \%$. This result is higher than in adults $45.3 \% .1$ The prevalence of dental caries in children in industrialized countries is 6090\%.4 Until now the prevalence and severity of dental caries in children under five in some countries in the world is sufficient high and tends to increase [4]. WHO targets that in 2020 at least $60 \%$ of children aged 5-6 years will be free of dental caries. This means that there are no cavities in all children's teeth. Children affected by dental caries in pre-school age sometimes do not have access to dental examinations, besides examining children's teeth their age is much more difficult than examining adult teeth.

Data on the dental and oral health status of children in Indonesia are still very limited, while the data is needed as input for the program in the effort to prevent dental disease through schools at an earlier level, namely preschool. Based on these problems, dental and oral health research was conducted on children aged 4-7 years.

\section{METHOD}

The research design was cross sectional. The study was conducted in the city of Bandung in 2018. The study population was all children aged 4-7 years in Indonesia. The research sample is children aged 4-7 years at the Az Zahra Foundation Bandung. The sample selection and 
research location were done by purposive random sampling. Research subjects consisted of children and parents (mothers) or caregivers who met the inclusion and exclusion criteria. The inclusion and exclusion criteria were boys or girls taken from the population of children aged 4-7 years and examined their teeth and willing to be involved in this study stated in the informed consent. The inclusion and exclusion criteria are mothers or caregivers who understand the history and condition of the respondents and are willing to be involved in this research stated in the informed consent.

Dependent variable was caries status and the independent variable consists of demographic status, tooth brushing behavior, duration of breastfeeding, routine dental health checkup. The duration of breastfeeding is grouped into two namely $>24$ months and $<24$ months. The instruments used were questionnaires, dental examination forms (dentogram), mouth mirror, sonde dental, tweezers, gloves, masks, mineral water, antiseptic liquid soap, $70 \%$ alcohol and dry tissue. Data on children's characteristics were asked to their parents using a questionnaire. Dental health status was examined by dentists using sterile instruments. Data were analyzed univariately to obtain an overview of each variable. Bivariate analysis to determine the relationship between the independent variables with the dependent variable.

\section{RESULTS AND DISCUSSION}

Dental health examination was carried out on children aged 4-7 years in the number of 70 children. The results showed that the majority of children aged 7 years $28.6 \%$. Based on gender, most were male, $58.6 \%$. The habit of brushing teeth everyday which is $97.1 \%$. Based on the frequency of brushing your teeth every day, it is mostly twice, that is 72.9\%. But not all children have the right brushing behavior. The results of research on correct tooth brushing behavior are only $11.4 \%$. Awareness to check dental health routinely twice a year is still low at $11.4 \%$. Based on breastfeeding, not all children get milk for 24 months $(52.9 \%)$. Most children experience dental caries by $81.4 \%$.

Table 1 shows the results of bivariate analysis between gender and dental caries obtained by girls having more dental caries than boys $(89.7 \%)$. However, there was no significant difference between the gender and the incidence of dental caries $(p=0.137)$. Age analysis of dental caries obtained by children aged 6 years more experienced dental caries (100\%). However, there was no significant difference between age and dental caries $(\mathrm{p}=$ 0.077).

The results of analysis of daily brushing behavior towards dental caries were obtained by children who did not brush their teeth every day more experienced dental caries $(100 \%)$. But there was no significant difference between daily tooth brushing behavior and dental caries $(\mathrm{p}=0.493)$. Based on bivariate analysis between the frequency of brushing teeth a day against dental caries obtained children who brush their teeth once a day have more dental caries $(100 \%)$. However, there was no statistically significant difference between the frequency of tooth brushing and dental caries $(\mathrm{p}=0.182)$.

The results of the analysis of the correct brushing behavior of dental caries obtained children who brushed teeth correctly had less dental caries $(25 \%)$. Statistically there was a significant difference between correct tooth brushing behavior and dental caries incidence $(p=0,000)$. Based on a bivariate analysis between routine dental health checks on dental caries events obtained by children who routinely check dental health less dental caries $(86.0 \%)$. However, there was no significant difference between routine dental health checks and dental caries $(p=0.151)$. Bivariate analysis results among children who were breastfed for 24 months or more on the incidence of dental caries obtained children who were breastfed $>24$ months more experienced dental caries $(83.3 \%)$. However, there was no statistically significant difference between the duration of breastfeeding $>24$ months and the incidence of dental caries $(p=0.592)$. Table 2 shows that the correlation value to brush teeth correctly has the greatest correlation value among other variables $(\mathrm{r}=0.521)$.

Table 1. Relationship of Variables with Dental Caries Children 4-7 years in Bandung City in 2018

\begin{tabular}{|c|c|c|c|c|c|c|c|c|}
\hline \multirow{3}{*}{\multicolumn{2}{|c|}{ Variable }} & \multicolumn{6}{|c|}{ Dental caries } & \multirow{3}{*}{ P } \\
\hline & & \multicolumn{2}{|c|}{ No } & \multicolumn{2}{|c|}{ Yes } & \multicolumn{2}{|c|}{ Total } & \\
\hline & & $n$ & $\%$ & $n$ & $\%$ & $n$ & $\%$ & \\
\hline \multirow{3}{*}{ Gender } & Boys & 10 & 24,4 & 31 & 75,6 & 41 & 100 & 0,137 \\
\hline & Girls & 3 & 10,3 & 26 & 89,7 & 29 & 100 & \\
\hline & 4 years & 4 & 33,3 & 8 & 66,7 & 12 & 100 & 0,077 \\
\hline \multirow{3}{*}{ Age } & 5 years & 5 & 26,3 & 14 & 73,7 & 19 & 100 & \\
\hline & 6 years & 0 & 0,0 & 19 & 100,0 & 19 & 100 & \\
\hline & 7 years & 4 & 20,0 & 16 & 80,0 & 20 & 100 & \\
\hline \multirow{2}{*}{$\begin{array}{l}\text { Tooth brushing } \\
\text { behavior }\end{array}$} & Yes, everyday & 13 & 19,1 & 55 & 80,9 & 68 & 100 & 0,493 \\
\hline & Not every day & 0 & 0,00 & 2 & 100,0 & 2 & 100 & \\
\hline \multirow{3}{*}{$\begin{array}{l}\text { Frequency of } \\
\text { brushing teeth }\end{array}$} & Once a day & 0 & 0,00 & 9 & 100,0 & 9 & 100 & 0,182 \\
\hline & Twice a day & 12 & 23,5 & 39 & 76,5 & 51 & 100 & \\
\hline & $>2$ Twice a day & 1 & 10,0 & 9 & 90,0 & 10 & 100 & \\
\hline \multirow{4}{*}{$\begin{array}{l}\text { Correct tooth } \\
\text { brushing behavior } \\
\text { Control to dentist } \\
\text { twice a year }\end{array}$} & Yes & 6 & 75,0 & 2 & 25,0 & 8 & 100 & 0,000 \\
\hline & No & 7 & 11,3 & 55 & 88,7 & 62 & 100 & \\
\hline & Yes & 13 & 100,0 & 49 & 86,0 & 62 & 88,6 & 0,151 \\
\hline & No & 0 & 0,0 & 8 & 100,0 & 8 & 100 & \\
\hline Duration of & $>=24$ months & 6 & 16,2 & 31 & 83,3 & 37 & 100 & 0,592 \\
\hline breastfeeding & $<24$ months & 7 & 21.2 & 26 & 78,8 & 33 & 100 & \\
\hline
\end{tabular}


breakfast and at night before going to sleep. The results of this study showed that the proportion of correct tooth brushing behavior was only $11.4 \%$. This result is slightly higher than the results of research in Bekasi, which is $10.5 \%$ [2]. This result is higher than Riskesdas 2018 which is only $2.8 \%$ [1].

Sintawati in her research showed that most children have bad oral habits. This is because the time to brush your teeth is not right, at night / sleep drinking sweet milk with a bottle and often eat sweet foods [2]. This study was obtained by children who brush their teeth correctly and had dental caries in the amount of $25.0 \%$. This result is higher compared to the results of Sabri's 2014 study, where children behave correctly and brush teeth with dental caries by $22.6 \%[13]$.

In this study the majority of respondents were boys $(58.6 \%)$. These results are consistent with the results of Zander's 2013 study in Australia and Kathy in the Indian Health Service Data Brief reported that the majority of respondents were boys [5,6]. However, these results are different from the results of Andayasari's research in Bekasi City in 2016, Suratri in Banten Province and DI Yogyakarta in 2014, and the results of Fenta's research in Ethiopia are mostly women [2,3,7]. This study obtained the majority of girls with dental caries $(89.7 \%)$. These results are consistent with the results of Andayasari's research in Bekasi City and Fenta in Ethiopia $(59.8 \%, 55 \%) .^{7}$ In this study it was found that gender factors had no effect on the occurrence of dental caries. In another study conducted in Brazil it was found that decay of primary teeth was related to parental education while permanent tooth decay was related to the gender [8].

By age, all children with dental caries were 6 years (100\%). The results of research in urban areas in India, that dental caries increased with increasing age [9]. The results of Iida research in 2007 in America [10] and Andayasari in Bekasi City in 2016 obtained the incidence of dental caries mostly occurs in children aged 5 years. Meanwhile, research in Virginia in 2014 revealed an increase in dental caries in children aged between 2 to 5 years [11]. In this study it was known that age did not affect the occurrence of dental caries.

Based on tooth brushing behavior, most respondents brush their teeth every day $(97.1 \%)$. These results are almost the same as the results of the Andayasari study in Bekasi in 2016 and Riskesdas 2018 (94.7\%) [1,2]. Children who do not brush their teeth every day have a higher incidence of caries $(20.9 \%$ vs $13.7 \%$ ) [12]. In addition there was an increased risk of caries development $(\mathrm{OR}=1.32 ; 95 \% \mathrm{CI}$ $=1.24-1.41)$ in boys $(\mathrm{OR}=1.30 ; 95 \% \mathrm{CI}=1.19-1.42)$ and girls (OR: $1.35 ; 95 \% \mathrm{CI}=1.23-1.49)$ [12].

Based on the frequency of brushing teeth, most children brush their teeth twice a day $(72.9 \%)$. This result is slightly higher than the results of Andayasari's study in Bekasi in $2016(73.1 \%)$ and in Yogyakarta City obtained 95\% [2,3]. The correct time to brush teeth is in the morning after
In this research, it is known that the behavior of teeth brushing correctly influences the occurrence of dental caries $(p=0,000)$ and there is a strong and direct correlation. However, some studies have shown that teeth brushing has a limited effect on reducing the incidence of caries because toothbrushes cannot remove plaque between teeth or in cracks on the surface of chewing. Fatimah's results showed that brushing daily by parents reduced the risk of developing caries [12]. Children without brushing teeth daily had a higher incidence of caries $(20.9 \%$ vs $13.7 \%)$ and increased the risk of caries (OR : 1.32; 95\% CI: 1.24-1.41) in both boys (OR: 1.30 95\% CI: $1.19-1.42)$ and girls (OR: 1,35 ; 95\% CI: $1.23-$ 1.49) [12].

Research findings highlight the need for preventive care programs to improve dental and oral health of children in Indonesia and the prospective determination of the relationship between children's oral health; school's selfesteem and academic achievement. ${ }^{14}$ Most of the literature on determinants of dental caries relates to socioeconomic and behavioral aspects: we found several studies evaluating the effects of the family environment and the oral hygiene behavior of their parents. Low socioeconomic status and poor oral hygiene practices were the influencing factors for dental caries. The results of the study state that children with highly educated, professional and highincome parents have a lower risk of dental caries [15]. Other study results suggest that dental caries in children is associated with daily brushing habits. Tooth brushing behavior is related to the self-efficacy of parents/ guardians in making their children brush their teeth twice a day [16].

This study revealed a strong positive relationship between caries development and the practice of brushing teeth. More frequent brushing will reduce the incidence of dental caries. Studies conducted in Brazil also state that the prevalence of dental caries is lower in children who have better oral hygiene [18]. Mouthwash is significantly associated with caries. A person who rinse their mouth after eating tend to be attacked by dental caries than those who don't rinse their mouth. This can be caused by washing away sugary nutrients from the teeth; therefore, micro- 
[3] Suratri M, Sintawati, Andayasari L, Muljati S, Nurhayati, Indirawaty. Pengetahuan, sikap dan perilaku tentang kesehatan gigi dan mulut pada anak usiataman kanak-kanak di Daerah Istimewa Jogjakarta dan Provinsi Banten tahun 2014. Media Penelitian dan Pengembangan Kesehatan. Vol. 26 No. 2, Juni 2016; 119-126. 2016.

[4] What is the Burden of Oral Disease? http:/www.who.int/oral health/disease burden/global/ en/index.html. Downloaded on January 13, 2014.

[5] A Zander, S Sivaneswaran, J Skinner, R Byun, B Jalaludin. Risk Factor for Dental Caries in Small rural and Regional Australian Communities. The International Electronic Journal of Rural and Remote Health Research, Education, Practice and Policy. 2013.

[6] Kathy R. Phipps, Timothy L. Ricks. The oral health of American Indian and Alaska Native Children Aged 1-5 years: Results of the 2014 HIS Oral Health Survey. Indian Health Service Data Brief. April 2015.

[7] Fenta A Ayele, Belaynew W Taye, Tadesse A Ayele, and Kassahun A Gelaye. Predictors of Dental caries among children 7-14 years old in northwest Ethiopia: a community based cross-sectional study. .BMC Oral Health 2013, 13 :7 http://www.biomedcentral.com/1472-6831/

[8] Hartwig AD, Romano AR, Azevedo MS. Prolonged Breastfeeding and Dental Caries In Children In the Third Year of Life. The Journal of Clinical Pediatric Dentistry Volume 43, Number 2/2019. doi 10.17796/1053-4625-43.2.4

[9] Prakash P, Subramaniam P, Durgesh B, Konde S. Prevalence of Early Childhood Caries and associated risk factors in preschool children of urban Bangalore, India. A crossectional study. Europian Journal of Dentistry. Volume 6, April 2012.

[10] Iida H, Auinger P, Billings RJ, Weitzman M. Association between infant breastfeeding and Early Chilhood Caries in the United States. PEDIATRICS. Volume 120, number 4. October 2007.

[11] Virginia. Prevention of dental cariesin children from birth through ade 5 years: US preventive services task force recommendation statement. 2014.

[12] Alim S, Fatimah. 2014. Pola makan dan kebiasaan menggosok gigi dengan timbulnya karies gigi pada anak. Journal of Pediatrics Nursing. Volume 1 (3). Hal 131-136. Juli 2014.

[13] Watanabe M, Wang DH, Ijichi A, Shirai C, Zou Y, Kubo M, Takemoto K, Masatomi C, Ogino K. The influence of lifestyle on the incidence of dental caries among 3-year-old japanese children: International Journal of Environmental Research and Public Health 2014, 11, 12611-12622;

[14] Maharani DA, Adiatma M, Rahardjo A, Burnside $G$ and Pine C. An assessment of the impacts of child oral health in Indonesia and associations with self-esteem, school performance and perceived employability. BMC Oral Health (2017) 17:65 DOI 
Public Health Vol.108, No.3, 2017.

[18] De Sousaa ET, Maiaa FBM, Alvesa VF, De Araújoa JSM, Fortea FDS, Sampaio FC. Dental caries in children assisted on a dental school clinic: prevalence and associated factors. Journal of Dental Science. Rev Odonto Cienc 2017;32(1):23-27. http://dx.doi.org/10.15448/1980-6523.2017.1.23281 [19] Rezvi1 FB, Abilasha R. Breast and Bottle Feeding as Risk Factors for Dental Caries-Review. Research Journal Pharmacy and Technology 2016. 9(9): 1508-1512. DOI:10.5958/0974-360X. 2016.00294.

[20] Avila WM, Pordeus IA, Paiva SM, Martins CC. Breast and Bottle Feeding as Risk Factors for Dental Caries: A Systematic Review and Meta-Analysis. PLOS ONE | DOI: 10.1371/journal. pone.0142922 November 18, 2015 